\title{
Isolation of mineralizing Nestin+ Nkx6.1+ vascular muscular cells from the adult human spinal cord
}

\author{
Daria Mamaeva ${ }^{1}$, Chantal Ripoll2 ${ }^{2}$ Claire Bony ${ }^{3}$, Marisa Teigell², Florence E Perrin ${ }^{4,5}$, Bernard Rothhut ${ }^{2}$, Ivan Bieche ${ }^{6}$, \\ Rosette Lidereau ${ }^{6}$, Alain Privat ${ }^{2}$, Valérie Rigau ${ }^{7}$, Hélène Guillon²${ }^{2}$, Florence Vachiery-Lahaye ${ }^{7}$, Daniele Noel ${ }^{3}$, \\ Luc Bauchet $^{7}$ and Jean-Philippe Hugnot ${ }^{2,8^{*}}$
}

\begin{abstract}
Background: The adult central nervous system (CNS) contains different populations of immature cells that could possibly be used to repair brain and spinal cord lesions. The diversity and the properties of these cells in the human adult CNS remain to be fully explored. We previously isolated Nestin ${ }^{+}$Sox $2^{+}$neural multipotential cells from the adult human spinal cord using the neurosphere method (i.e. non adherent conditions and defined medium).
\end{abstract}

Results: Here we report the isolation and long term propagation of another population of $\mathrm{Nestin}^{+}$cells from this tissue using adherent culture conditions and serum. QPCR and immunofluorescence indicated that these cells had mesenchymal features as evidenced by the expression of Snai2 and Twist1 and lack of expression of neural markers such as Sox2, Olig2 or GFAP. Indeed, these cells expressed markers typical of smooth muscle vascular cells such as Calponin, Caldesmone and Acta2 (Smooth muscle actin). These cells could not differentiate into chondrocytes, adipocytes, neuronal and glial cells, however they readily mineralized when placed in osteogenic conditions. Further characterization allowed us to identify the Nkx6.1 transcription factor as a marker for these cells. Nkx6.1 was expressed in vivo by CNS vascular muscular cells located in the parenchyma and the meninges.

Conclusion: Smooth muscle cells expressing Nestin and Nkx6.1 is the main cell population derived from culturing human spinal cord cells in adherent conditions with serum. Mineralization of these cells in vitro could represent a valuable model for studying calcifications of CNS vessels which are observed in pathological situations or as part of the normal aging. In addition, long term propagation of these cells will allow the study of their interaction with other CNS cells and their implication in scar formation during spinal cord injury.

Keywords: human central nervous system, spinal cord, stem cells, vascular muscle cells, osteogenesis, Nkx6.1, calcification

\section{Background}

It is now well established that the CNS contains a pool of neural stem and progenitor cells that are either located in specific locations called niches or dispersed in the parenchyma, notably in the white matter. These cells can be isolated using a cell sorting strategy based on the expression of markers such as CD133 and A2B5. They typically grow on non adherent substrates when they generate clonal expansions called neurospheres [1],

\footnotetext{
* Correspondence: hugnot@univ-montp2.fr

${ }^{2}$ INSERM U1051, Institut des Neurosciences de Montpellier, Hôpital St ELOI, BP 74103 80, av Augustin Fliche, 34091 Montpellier Cedex 05, France
} Full list of author information is available at the end of the article which on differentiation, generate glial cells and neurons. This endogenous pool of immature cells is activated and recruited in several CNS pathologies such as stroke or degenerative diseases in an attempt to compensate for the cellular loss. Much of our knowledge on these cells is derived from studies performed in rodents, but much less is known on these stem cells in human. Adult neural stem and progenitor cells have been isolated from different parts of the human brain, namely the olfactory bulb, the subventricular zone, the hippocampus, the cortex, using the neurosphere assay [2-9]. More recently, using adherent conditions and a specific media, adult human neural precursors have been

\section{() Biomed Central}


isolated from the human temporal cortex and the hippocampus [10]. These cells express glial markers and are able to generate both glial and mature neuronal cell types in vivo and in vitro. They could represent a potential endogenous cellular source that could be used to alleviate neuronal loss which occurs in many CNS diseases. However, much more work is needed to isolate and characterize these cells from different human CNS locations and, in particular, to analyse the signalling mechanisms leading to their differentiation.

Besides neural stem cells, the adult CNS might also contain a pool of mesenchymal stem cells (MSC) which appear to differentiate into mesenchymal lineage cells (adipocytes, osteoblasts and chondroblasts) and possibly neural lineage cells. However this has mainly been observed in mice [11] and the actual differentiation capacity of these cells remains to be validated in detail.

Compared to brain, little is known about neural precursors in the adult spinal cord [12]. We recently isolated multipotential cells in the human adult spinal cord using the neurosphere method [13]. In this article, we set out to explore the possibility of isolating adult neural stem/progenitor cells from the adult human spinal cord using adherent conditions previously described [10]. We found that these conditions mainly result in the propagation of mesenchymal cells expressing Snai2 and Twist1 and with the hallmarks of smooth muscle muscular cells. These cells do not appear to be MSC, nor neural stem cells, but they can readily mineralize in vitro when placed in appropriate conditions. Additional characterization of these cells allowed us to identify the Nkx6.1 homeodomain transcription factor as a marker for these cells.

\section{Results}

Isolation of Nkx6.1 $1^{+}$vascular muscular cells from adult human spinal cord

To isolate human neural stem cells using adherent condition as used in [10], human spinal cord was rapidly processed as previously described [13] and seeded with neural stem cell medium containing serum and EGF/ FGF. Under these conditions, cells with a mesenchymal morphology (Figure 1A) grew rapidly and could be propagated for approximately 3 months (approximately 25 divisions and 9-10 passages) before undergoing proliferation decrease, probably as a consequence of cellular senescence (Figure 1B). The cells were characterized at passage 4 by QPCR and immunofluorescence. We first measured the expression of genes typically expressed by cells of the neural lineage, i.e astrocytes (Aldh1l1, Gfap), oligodendrocytes (Cnp, Mbp, Plp1, Sox10, Ugt8), oligodendrocyte progenitor cells (Ascl1, Nkx2.2, Nkx6.1, Olig1/2, Pdgfr $\alpha / \beta)$, neurons (Dcx, Nefl) and stem cells (Fabp7/Blbp, Nestin, Prominin/CD133, Sox2).
Surprisingly, although these cells were derived from the CNS, we found that the expression of these genes was either low or undetectable (Figure 1C, D) and only Nestin, Cnp and $P d g f R \alpha / \beta$ could be detected with less than 25 cycles of QPCR. We confirmed by immunofluorescence the absence of detectable expression of Sox2, GFAP and Olig2 which are well documented markers for neural stem cells and glial cells (Figure 2A). We then questioned the presence of markers frequently expressed in mesenchymal cells (Acta2, CD44, Col1A1, Fn1, Vim, Tgfß1), bearing in mind that these can also be found expressed in cells of the neural lineage, and mesenchymal transcription factors (FoxC2, Snai1/2, Twist1, Zeb1/2). In sharp contrast with the neural lineage genes, the expression of these genes was readily detected (Figure 1C, D). We confirmed by immunofluorescence and western blot that Snai2 and Twist1 were expressed at the protein level (Figure 2A, B). These two transcription factors were detected in the nuclei of most cells (>80\%) (Figure 2A).

The possibility existed that the isolated cells were derived from the in vitro differentiation of endogenous spinal neural precursor cells which would adopt a mesenchymal phenotype when cultured in serum-containing medium. To explore this hypothesis, we cultured human fetal brain neural stem cells in this medium for three passages and then explored the phenotype of these cells by QPCR and immunofluorescence (Figure 1C, D, 2A). In contrast with cells isolated from the adult spinal cord, our immunofluorescence analysis revealed that these cells expressed a high level of several typical neural markers such as GFAP, Sox2, Olig2 whereas Snai2 and Twist1 were not detectable (Figure 2A). QPCR confirmed these results and further indicated the maintenance of several typical markers for neural cells (for instance CD133/Prom1, Dcx, PLP1 respectively for stem, neuronal and oligodendrocytic cells) even when cultured in serum-containing media (Figure 1C, D).

The high expression of transcripts for smooth muscle actin (Acta2) in spinal cord cells suggested that the culture contained a majority of vascular muscular cells, an assumption consistent with the detection of Nestin and $P d g f R \alpha / \beta$ (Figure 1C), two markers also expressed by vascular cells $[14,15]$. In order to confirm this possibility, we explored by immunofluorescence the expression of Acta 2 and Nestin, together with Calponin, Caldesmon and NG2, three other markers of vascular muscular cells. The vast majority of the cells $(>80 \%)$ were positive for these five proteins, confirming that these cultures mostly contained vascular muscular cells (Figure 3A-E).

One unexpected transcription factor detected in the culture by QPCR was Nkx6.1 (Figure 1D). This homeodomain protein is implicated in the ontogenesis of oligodendrocytes and of pancreatic cells $[16,17]$ but its 


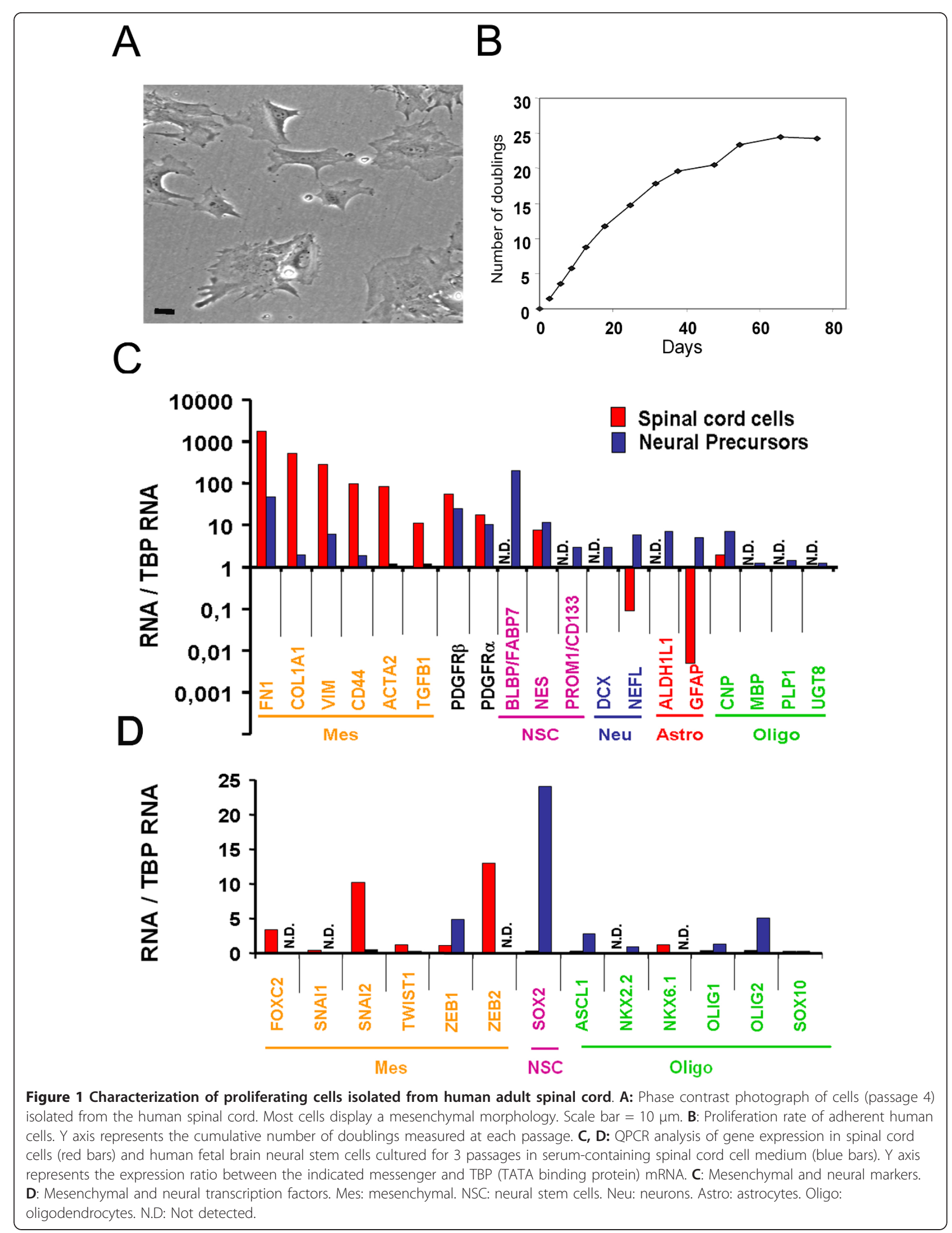




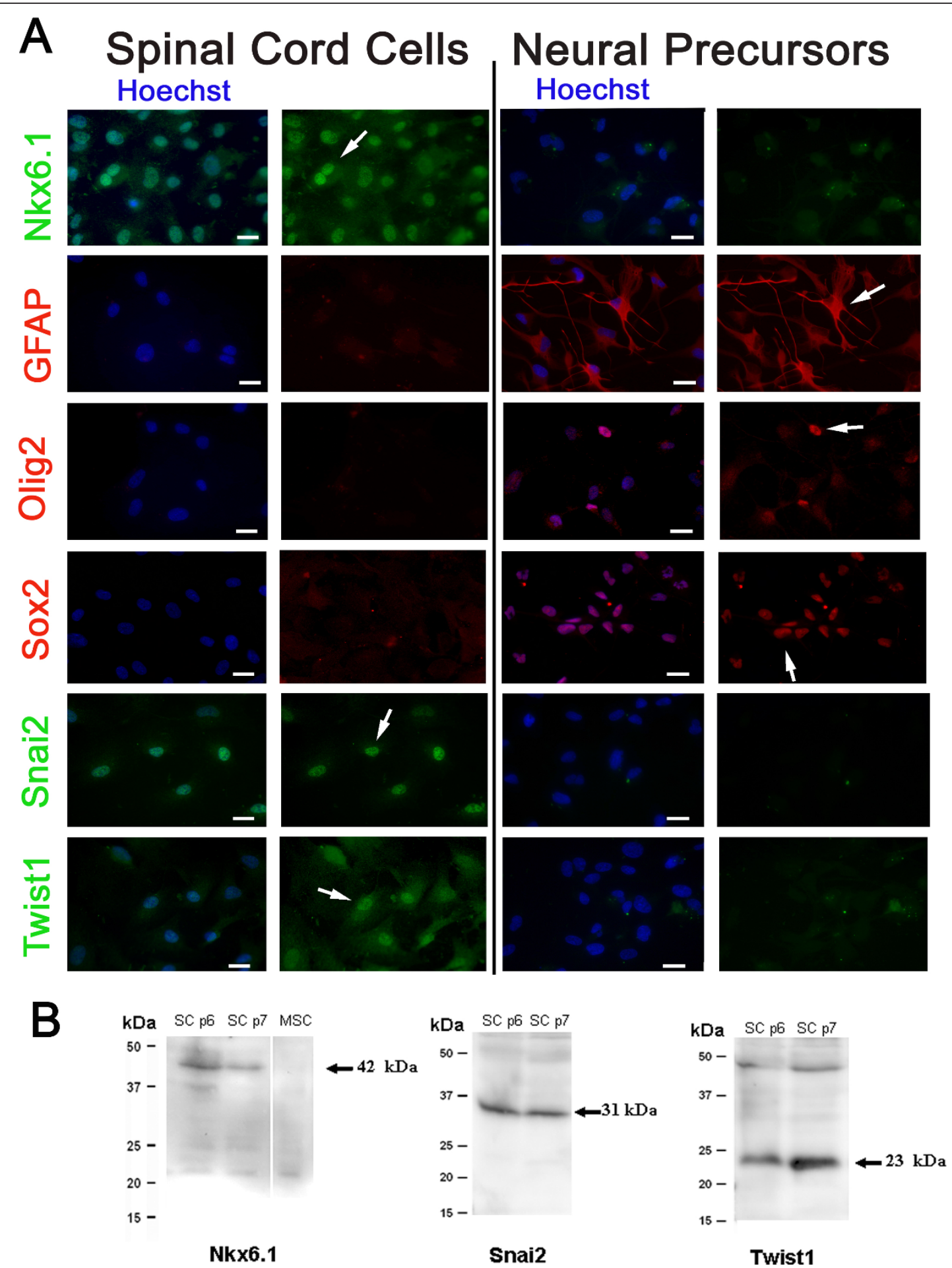

Figure 2 Immunofluorescence characterization. A: Spinal cord cells and human fetal neural stem cells (cultured for 3 passages with serumcontaining spinal cord cell medium) were labelled with indicated antibody. Arrows show examples of stained cells. Scale bars $=10 \mu \mathrm{m}$. B: Western blot analysis for indicated antibodies. A main band at the expected size is observed for the three antibodies in spinal cord stem cells. SC p6, SC p7: spinal cord cells analysed at passages 6 and 7. MSC: human mesenchymal stem cells isolated from bone marrow. 

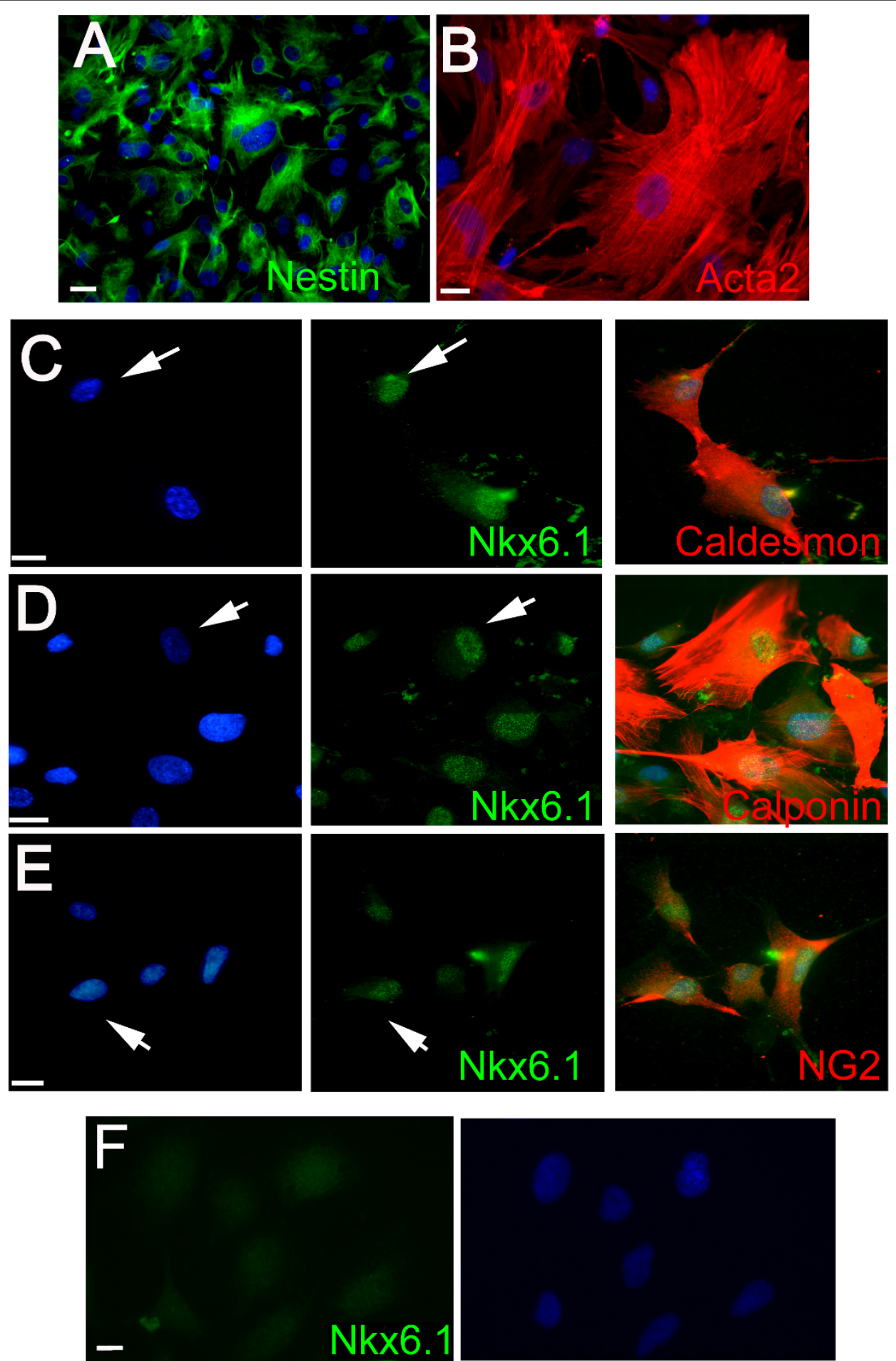

Figure 3 Expression of smooth muscle markers and Nkx6.1 in spinal cord cells. A-F: Immunofluorescence staining of spinal cord cells (A-E) and human mesenchymal stem cells (F). The vast majority of cells (>80\%) express Nestin, Acta2, Caldesmon, Calponin and NG2. Nuclear Nkx6.1 staining is detected in Caldesmon ${ }^{+}$, Calponin ${ }^{+}, \mathrm{NG}^{+}$spinal cord cells $(\mathbf{C}, \mathbf{D}, \mathbf{E})$ but not in human mesenchymal stem cells $(\mathbf{F})$. Scale bars $=10 \mu \mathrm{m}$. 
expression in vascular cells has not been reported in adults. The presence of Nkx6.1 protein was confirmed by immunofluorescence and western blot in these cultures (Figure 2A, B). The vast majority of the cells $(>80 \%)$ showed a clear nuclear staining and these cells coexpress Calponin, Caldmesmon and NG2 (Figure 3C, D, E). In contrast, Nkx6.1 was not detected in human fetal neural stem cells cultured in the same conditions for three passages (Figure 2A). The expression of Nkx6.1 by vascular cells was then confirmed in vivo on adult human spinal cord sections. $\mathrm{Nkx6.1^{+ }}$ cells were detected around large vessels in the meninges and in the parenchyma (Figure 4A, B). As previously reported [13], Nkx6.1 was also expressed by ependymal cell of the central canal (data not shown). We concluded from these data that adherent cultures derived from adult human spinal cord led to the isolation of a cellular population mainly composed of vascular muscular cells that express the homeodomain protein Nkx6.1 and the mesenchymal transcription factors Snai2 and Twist1.

\section{$\mathrm{Nkx} 6.1^{+}$cells are not multipotential stem cells but mineralize in vitro}

It has recently been reported that adult stem cells with mesenchymal features located in various tissues could behave as multipotential stem cells [11,18-21]. These cells could give rise to cells of several lineages including neurons and myelinating cells. We thus explored the multipotentiality of $\mathrm{Nkx} 6.1^{+}$cells by placing them in different media and culture conditions. First, by culturing them in non adherent conditions in defined neural stem cell medium, these cells were not able to form neurospheres, a hallmark of neural stem cells. Second, we further examined the possibility of a neural differentiation by labelling the cells with a GFP-expressing lentivirus, then by coculturing them for 2 weeks with human young neurons, obtained by differentiation of human fetal brain neural stem cells. In these conditions, we could not detect staining of GFP-labelled cells (100 individual cells examined) with neuronal (Map2ab), astrocytic (GFAP) or oligodendrocytic (Olig2, Nkx2.2) markers, strongly indicating the absence of neural differentiation of these cells (Figure 5). Third, we treated the cells with BMP2, BMP4, BMP7, CNTF, CNTF/BMP4, LIF, LIF/ BMP4 or T3 to promote an astrocytic $[22,23]$ or an oligodendrocytic fate [24] respectively, but again no differentiation was observed (data not shown).

Considering the mesenchymal features of these cells and as vascular muscular cells have been reported to be endowed with stem cell properties $[18,20]$ we next examined the capacity of $\mathrm{Nkx} 6.1^{+}$cells to generate chondrocytes, adipocytes and osteoblasts, three lineages commonly produced by mesenchymal stem cells. The cells were placed in adequate media, and the

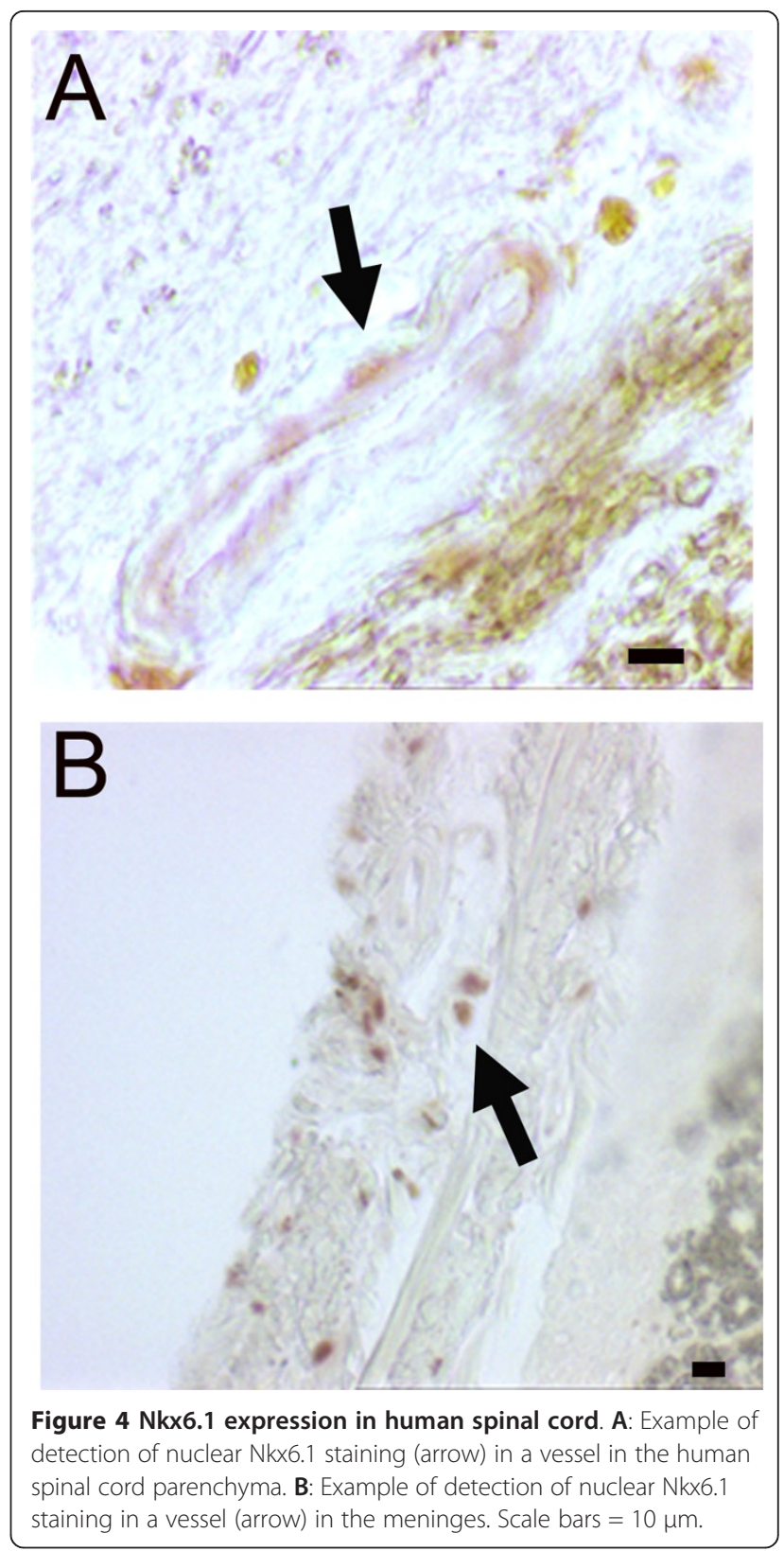

differentiation was monitored by staining with Oil red $\mathrm{O}$ (adipogenesis), Alizarine red S (osteogenesis) and Alcian blue (chondrogenesis) and by QPCR for markers for adipocytes (Lpl, Fabp4, PPARg), chondrocytes (Col2b, Col10, Aggregan, Mmp13, Comp, Sox9) and osteoblasts (SPARC, Osteocalcin, Runx2, phosphatase alkaline). As a control, the differentiation of human mesenchymal stem cells isolated from bone marrow was monitored in parallel. Under these conditions, no differentiation towards chondrocytes or adipocytes was observed (not shown). Only deposition of calcium phosphate precipitates, as observed with Alizarine red $\mathrm{S}$ staining (Figure 6A), could convincingly be detected. This was 

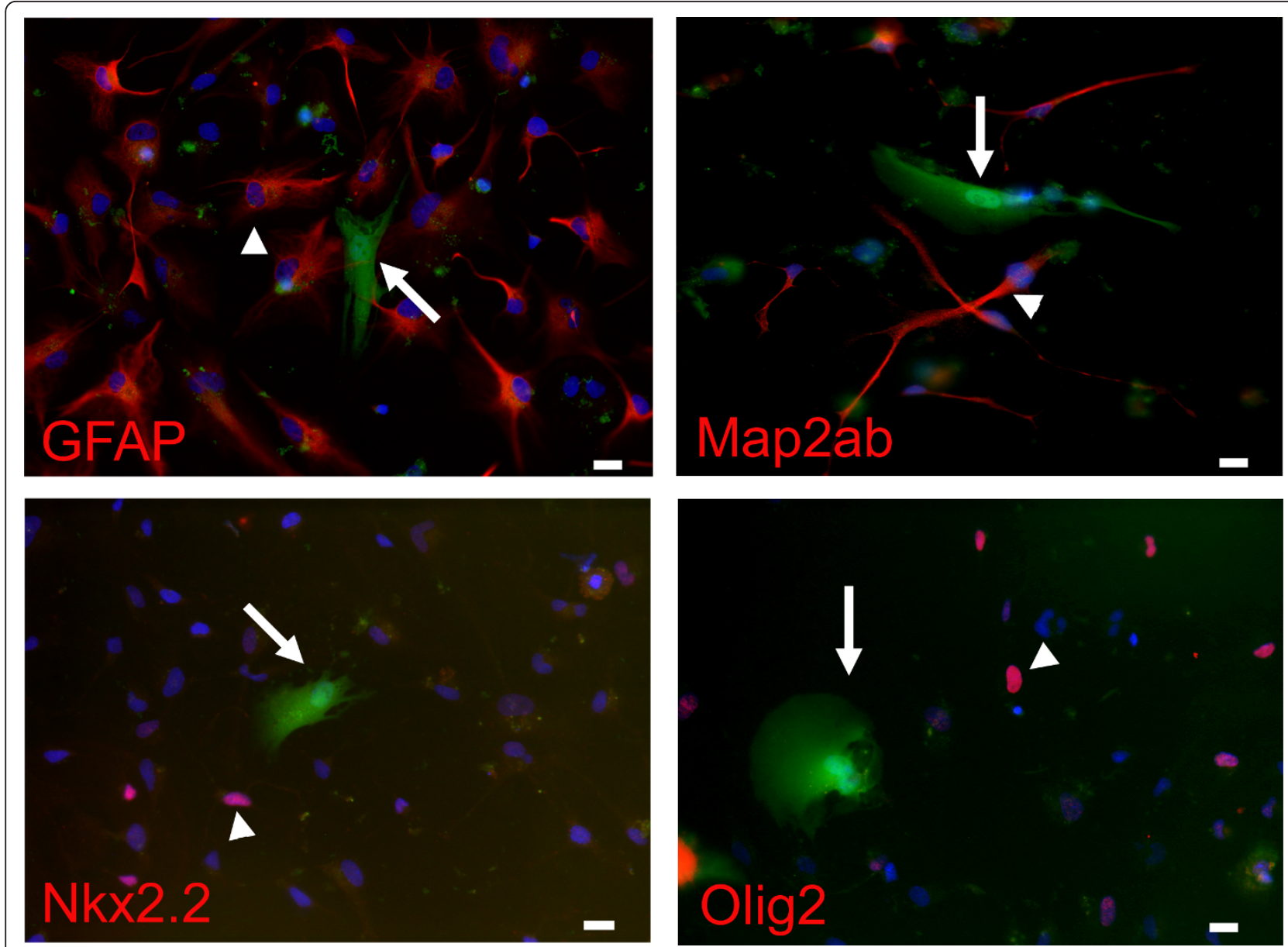

Figure 5 Co-culture of spinal cord cells with differentiated human fetal brain neural stem cells. Spinal cord cells labelled with GFPexpressing lentivirus (green fluorescence, arrows) do not stain with GFAP, Map2ab, Olig2 and Nkx2.2 antibodies (red) in contrast to neural precursor cells (arrowheads). Scale bars $=10 \mu \mathrm{m}$.

accompanied by a sharp increase of alkaline phosphatase mRNA (Figure 6B) and activity which was detected with Naphthol ASBI phosphate and Fast Red Trisodium staining (Figure 6C). No increase of the other osteoblast markers compared to that obtained with bone marrow mesenchymal stem cells could be demonstrated (not shown) suggesting absence of complete differentiation towards osteoblasts. Equally, we could not detect the expression of Nkx6.1 by western blot (Figure 2B) and immunofluorescence (Figure 3F) in bone marrow mesenchymal stem cells, suggesting that CNS Nkx6.1 $1^{+}$ vascular cells are weakly related to these cells. We also examined the capacity of human fetal neural stem cells cultured in the presence of serum to mineralize in the same conditions. Figure 6A, C shows however that these cells were unable to do so.

Finally, to ascertain that mineralization was produced by $\mathrm{Nkx} 6.1^{+}$cells and not by other contaminating cell types, we performed single cell cloning in 96 wells to isolate $\mathrm{Nkx6.1^{+ }}$ cell clones which were then placed in mineralizating conditions. Among 34 isolated Nkx6.1 $1^{+}$ clones, $95 \%$ of them were able to mineralize (Figure 6D). We concluded from these studies that Nkx6.1 $1^{+}$vascular muscular cells isolated from the adult CNS do not behave as neural or mesenchymal stem cells but can readily mineralize in vitro.

\section{Discussion}

Neural stem cells are generally isolated and cultured using non adherent conditions and defined medium to generate free-floating aggregates, the so-called neurospheres. Adherent cultures with serum-containing medium have also been successfully used to isolate and culture adult neural stem cells from adult human brain (temporal lobe). We previously reported the isolation of human spinal cord stem/progenitor Sox ${ }^{+}$cells using the neurosphere method [13], however we were unable to identify such cells using adherent conditions in the 


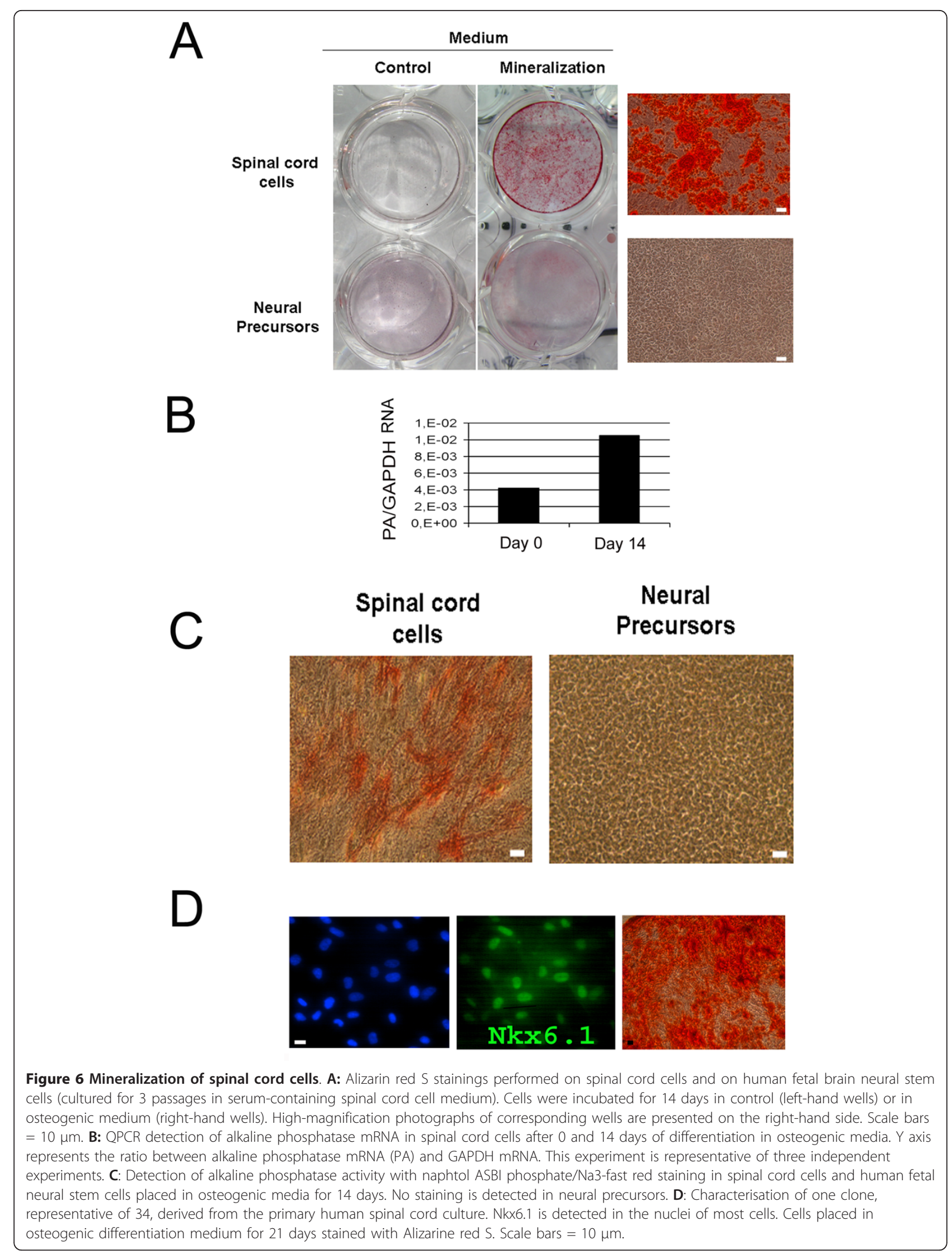


present study. Considering the low number of these cells as compared to other spinal cord cells, it is possible that these cells are rapidly diluted during the culture passages. Alternatively it is conceivable that the presence of serum leads to their premature differentiation.

We report here that, in contrast to neural stem/progenitor cells, these conditions lead to the isolation of a cellular population mainly composed of $\mathrm{Nkx6.1^{+ }}$ vascular muscular cells. Although these cells express some markers for neural and mesenchymal stem cells, such as Nestin or CD44, they do not behave as multipotential stem cells, at least in the conditions we employed. In fact, only differentiation along the osteogenic lineage, as evidenced by their ability to mineralize in vitro, was observed. The calcification of brain vessel muscle cells has been observed since $1884[25,26]$ in pathological situations or as part of the brain aging process [27]. In elderly brains, mild calcification of vessels and parenchyma is a normal and common incidental finding in the basal ganglia, pineal gland, choroid plexus, dura and habenula. This vasculopathy may account for the sclerosis of the aged hippocampus and the concomitant loss of CA1 neurons [28].

There is also now clear evidence for a close association between vasculature and neurogenesis [29], the socalled vascular stem cell niche, and the observation of an age-related neurogenesis decline [30] may be related to some modifications of vascular cell properties. In addition, recent work by Göritz C, et al [31] demonstrated a critical role of vascular cells in the formation of the scar following spinal cord injury. The extensive growth of Nkx6.1 $1^{+}$human vascular muscular cells under our conditions will allow further studies on their interactions with adult neural stem cells, their role in the aging process and their implication in the scar formation.

Nkx6.1 is a homeodomain protein that plays a major role in CNS development, notably in spinal cord [32]. Being a target of the ventralizing $\mathrm{SHH}$ morphogen, Nkx6.1 is required for motoneuron generation and correct oligodendrogenesis. In agreement with the detection of Nkx6.1 in adult spinal cord meninges (Figure 4), Nkx6.1 is also expressed in ventral meninges during spinal cord development [33]. Outside the CNS, Nkx6.1 is required for pancreatic $\beta$-cell development and its disruption results in $90 \%$ decrease of these cells [16]. Nkx6.1 is also detected in esophageal and tracheal smooth muscle cells during development [33]. Consistent with this observation, we report here that in the adult human spinal cord, vascular smooth muscle cells express this transcription factor in vitro and in vivo. Its role in these cells remains to be explored. As Nkx6.1 is implicated in the positive regulation of $\beta$-cell proliferation [34], notably by direct interaction with the cyclin
A2 and B1 promoters, a similar function could be hypothesized for CNS vascular muscular cells proliferation.

\section{Conclusions}

In this study we have isolated vascular cells from the human adult spinal cord and showed that these cells are neither endowed with mesenchymal nor neural stem cell properties. We demonstrated that these cells express the developmental homedomain protein Nkx6.1, two mesenchymal transcription factors (Snai2 and Twist1) and that they can readily mineralize when placed in osteogenic conditions. These cells constitute a useful model for studying CNS vessel calcification in vitro.

\section{Methods}

\section{Cell culture}

Human spinal cord was obtained from one organ-donor patient (40 years old, accidental death) in strict agreement with the French bioethics laws (articles L1232-1 to L1232-6) and after approval by the French institution for organ transplantation. An informed consent from the family was obtained by the organ procurement organization (OPO) for this study. A sample of the lumbar spinal cord was removed and rapidly processed for cell culture as previously described [13]. Cells were cultured at approximately $4 \times 10^{3}$ per $\mathrm{cm}^{2}$ cell culture flasks in the presence of DMEM/F12 with L-glutamine complemented with N2 supplement (Fischer Scientific, http:// www.fishersci.com), $35 \mu \mathrm{g} / \mathrm{ml}$ of bovine pituitary extract (Fischer Scientific), 5\% of certified fetal calf serum (Fischer Scientific), $20 \mathrm{ng} / \mathrm{ml}$ of human EGF and FGF2 (Peprotech, http://www.peprotech.com), heparin (2 $\mu \mathrm{g} /$ $\mathrm{ml})$, ciprofloxaxine $(2 \mu \mathrm{g} / \mathrm{ml})$, gentamycin $(10 \mu \mathrm{g} / \mathrm{ml})$ (Fischer Scientific), fungizone $(0.25 \mu \mathrm{g} / \mathrm{ml})$ (Fischer Scientific), fungin $(10 \mu \mathrm{g} / \mathrm{ml})$ (Invivogen, http://www. invivogen.com). Media was replaced twice a week and cells were passaged at $80-90 \%$ confluency using a $3 \mathrm{~min}$ dissociation step at $37^{\circ} \mathrm{C}$ with Trypsin/EDTA (Fischer Scientific) containing $0.25 \%$ Trypsin. Cells were frozen in complete media containing $10 \%$ DMSO. For cloning experiments (Figure 6D), the cell culture was dissociated and single cell seeding in 96 well plates was performed using an Aria cytometer (BD, http://www.bdbiosciences. com) equipped with an automated single cell deposition device. After 3 weeks, each clone was split in two and expanded to perform Nkx6.1 staining and osteogenic differentiation.

\section{Differentiation into neurons, astrocytes and myelinating cells}

To assess the capacity of human adult spinal cord cells to differentiate into oligodendrocytic, astrocytic or neuronal cells, cells were seeded on differentiated human 
fetal brain neural stem cells. The latter were obtained by growing human fetal brain neural stem cells (16 weeks of gestation, Lonza, http://www.lonza.com) as neurospheres then by differentiating them on laminin-coated coverslips to generate young neurons and glial cells according to the manufacturer's protocols. Spinal cord human cells were pre-labelled using an infection with a GFP-expressing lentivirus to distinguish them from fetal brain cells. Cells were co-cultured for 1-2 weeks before assessing their differentiation into glial and neuronal cells using neural lineage markers (Map2ab, Gfap, Olig2, Nkx2.2). To assess the capacity of the spinal cord cells to differentiate into astrocytes, cells were treated by BMP2 (10 ng/ml), BMP4 (10 ng/ml), BMP7 (10 ng/ml), LIF $(10 \mathrm{ng} / \mathrm{ml})$, LIF + BMP4, CNTF $(10 \mathrm{ng} / \mathrm{ml})$ or CNTF+BMP4 for 4 days before staining for GFAP. For oligodendrocytic differentiation, cells were treated for one week with $15 \mathrm{nM}$ Triiodo-L-Thyronine (T3) (Sigma, http://www.sigmaaldrich.com) + N2 supplement (Fischer Scientific, http://www.fishersci.com) or Neurobasal media with B27 and vitamin A, before staining for GalC and $\mathrm{O} 4$ antigens.

\section{Differentiation into adipocytes, chondroblasts and osteoblasts}

As a control, the differentiation of human mesenchymal stem cells isolated from bone marrow as described in [35] was monitored in parallel with spinal cord cells and human fetal neural stem cells. For adipogenic differentiation, cells were plated at a density of $8 \times 10^{3}$ cells/ $\mathrm{cm}^{2}$ in DMEM-F12 containing 5\% newborn calf serum, $1 \mu \mathrm{M}$ dexamethasone, $50 \mu \mathrm{M}$ isobutyl-methylxanthine and $60 \mu \mathrm{M}$ indomethacin. Stimulation was carried out for 3 weeks with the medium changed every 2-3 days. Adipocyte differentiation was confirmed on day 21 by visualization of lipid droplets by oil red $\mathrm{O}$ staining and QPCR using primers as described in [35]. For chondrogenic differentiation, cells were cultured in $15 \mathrm{ml}$ polypropylene conical tubes with $2.5 \times 10^{5}$ cells, after centrifuging for $5 \mathrm{~min}$ at $600 \mathrm{~g}$. The resulting pellets were cultured in $500 \mu \mathrm{l}$ DMEM supplemented with 0.1 $\mu \mathrm{M}$ dexamethasone, $0.17 \mathrm{mM}$ ascorbate- 2 phosphate, $1 \%$ insulin-transferrin-sodium selenite supplement and $10 \mathrm{ng} / \mathrm{ml}$ of recombinant TGF $\beta 3$ (R\&D Systems). Media were changed every 2-3 days. Differentiation was assessed on samples on day 21 by QPCR using specific primers [35]. Osteogenesis was induced in spinal cord cells and human fetal brain neural stem cells by culturing at low density $\left(2.5 \times 10^{3}\right.$ cells $\left./ \mathrm{cm}^{2}\right)$ in osteogenic medium consisting of DMEM (high glucose) with 10\% fetal calf serum, $10 \mathrm{mM} \beta$-glycerophosphate, $0.1 \mu \mathrm{M}$ dexamethasone, $0.05 \mathrm{mM}$ ascorbic acid (Sigma) and $\mathrm{NaH}_{2} \mathrm{PO}_{4} 3 \mathrm{mM}$. Medium was changed every three days for 2 weeks. Osteoblast differentiation was assessed on day 14 by visualization of matrix calcification by Alizarin red S staining and QPCR as previously described [35]. Phosphatase alkaline activity detection by naphthol ASBI phosphate and Fast Red Trisodium staining was performed as previously described [36]. In this condition, cells were cultured for 2 weeks in osteogenic medium but without $\mathrm{NaH}_{2} \mathrm{PO}_{4}$.

\section{Histology and immunodetection}

For paraffin sections, human lumbar spinal cord samples were fixed in formaldehyde-acetic acid-methanol (10\%$10 \%-40 \% \mathrm{v} / \mathrm{v}$ ) for $72 \mathrm{~h}$, embedded in paraffin, then processed for antigen demasking by boiling for $40 \mathrm{~min}$ in EDTA $10 \mathrm{mM}$ pH 7.2. Immunoperoxydase detection (diaminobenzidine, Dako) was performed as previously described [13] on $4 \mu \mathrm{m}$ paraffin sections. Immunodetection was performed on cell cultures as previously described in [37]. Nuclei were stained with $2 \mu \mathrm{g} / \mathrm{ml}$ Hoechst 33242. The following primary antibodies were used: Acta2 (1:100, mouse monoclonal, 1A4, Sigma), Caldesmon (1:250, rabbit monoclonal, Abcam AB32330), Calponin (1:250, rabbit monoclonal, Abcam AB46794), GFAP (1:1000, rabbit polyclonal, Dako Z0334), Map2ab (1:500, mouse monoclonal HM-2, Sigma), Nestin (1:1000, rabbit polyclonal, Chemicon AB5922), Nkx2.2 (1:40, mouse monoclonal 74.5A5, Developmental Biology Hybridoma Bank, University of Iowa), Nkx6.1 (1:100, mouse monoclonal F55A10, Developmental Biology Hybridoma Bank), Olig2 (1:500, rabbit polyclonal, IBL 18953), Snai2 (1:50, rabbit monoclonal, Cell Signalling C19G7), Twist1 (1:2, mouse monoclonal, Abcam AB50887). Cy3 or Cy5 conjugatedsecondary antibodies (1:500, Invitrogen) were used.

\section{QPCR analysis}

RNA extractions from spinal cord cells (passage 4) and human fetal brain neural stem cells (cultured in spinal cord cell medium for three passages) were performed using kits from Qiagen http://www.qiagen.com. Quantitative real-time RT-PCR was performed as described previously [38]. PCR was performed using the SYBR Green PCR Core Reagents Kit (Perkin-Elmer Applied Biosystems). The thermal cycling conditions comprised an initial denaturation step at $95^{\circ} \mathrm{C}$ for $10 \mathrm{~min}$ and 50 cycles at $95^{\circ} \mathrm{C}$ for $15 \mathrm{~s}$ and $65^{\circ} \mathrm{C}$ for $1 \mathrm{~min}$. Experiments were performed with duplicates for each data point. Primer sequences are provided as additional file 1, Table S1. We quantified transcripts of the TBP gene (TATA binding protein) (Figure 1) or GAPDH (Figure 6) as the endogenous reference RNA control. Results, expressed as $n$-fold differences in target gene expression relative to the reference gene (termed Ntarget), were determined with the following formula: Ntarget $=2^{\Delta \mathrm{Ct}}$ sample, where the $\Delta \mathrm{Ct}$ value of the sample was determined by 
subtracting the average $\mathrm{Ct}$ value of the target gene from the average $\mathrm{Ct}$ value of the reference gene.

\section{Western blot analysis}

Protein preparation and Western blot procedure were described in [39]. Precision Plus Protein WesternC Standards were used (Bio-Rad).

\section{Additional material}

Additional file 1: Table S1: Table of primers used in QPCR analysis (Figure 1C, D).

\section{Acknowledgements and fundings}

This work was supported by the European Union FP6 « Rescue » STREP, the "Association Française contre les Myopathies" (Evry, France) and the "Fondation Thérèse et René Planiol pour l'étude du Cerveau" (Varennes, France). We thank Dr C Duperray (cytometry facilities), Dr H Boukhaddaouin and C Sar (RIO cell imaging facilities), I Sassetti (RHEM histology facilities) and $Y$ Gerber/G Boniface for high quality technical assistance. We are grateful to Montpellier neurosurgery and pathology departments for providing spinal cord samples.

\section{Author details}

${ }^{1}$ CNRS UPR 1142, Institute of Human Genetics, 141, rue de la Cardonille, 34396 Montpellier Cedex 05, France. ${ }^{2}$ INSERM U1051, Institut des Neurosciences de Montpellier, Hôpital St ELOI, BP 74103 80, av Augustin Fliche, 34091 Montpellier Cedex 05, France. ${ }^{3}$ INSERM U844, Institut des Neurosciences de Montpellier, Hôpital St ELOI, BP 74103 80, av Augustin Fliche, 34091 Montpellier Cedex 05, France. ${ }^{4}$ IKERBASQUE, Basque Foundation for Science, 48011 Bilbao, Spain. ${ }^{5}$ Department of Neuroscience, Faculty of Medicine and Odontology, University of the Basque Country UPV/ EHU, 48940 Leioa, Spain. ${ }^{6}$ INSERM U735, Institut Curie - Hôpital René Huguenin, 35 rue Dailly, 92210 Saint-Cloud, France. ${ }^{7} \mathrm{CHU}$ Montpellier, Hopital Guy de Chaulliac, Montpellier, France. ${ }^{8}$ Université Montpellier 2, Place Eugène Bataillon, 34095 Montpellier cedex 5, France.

\section{Authors' contributions}

DM, CB, MT, DN, HG carried out cell culture, cell characterization and differentiation. CR, VR, BR performed spinal cord immunochemistry and western blot analyses. IB, RL carried out the OPCR analysis. LB, FEP carried out the spinal cord removal. AP participated in the design and coordination of the study. FV implemented the spinal cord removal procedure in the Montpellier Hospital. JPH designed and supervised the experiments and wrote the article.

All authors read and approved the final manuscript.

Received: 17 August 2011 Accepted: 10 October 2011

Published: 10 October 2011

\section{References}

1. Reynolds BA, Weiss S: Generation of neurons and astrocytes from isolated cells of the adult mammalian central nervous system. Science 1992, 255(5052):1707-1710.

2. Arsenijevic Y, Villemure JG, Brunet JF, Bloch JJ, Deglon N, Kostic C, Zurn A, Aebischer $\mathrm{P}$ : Isolation of multipotent neural precursors residing in the cortex of the adult human brain. Exp Neurol 2001, 170(1):48-62.

3. Roy NS, Wang $S$, Jiang L, Kang J, Benraiss A, Harrison-Restelli C, Fraser RA Couldwell WT, Kawaguchi A, Okano H, Nedergaard M, Goldman SA: In vitro neurogenesis by progenitor cells isolated from the adult human hippocampus. Nat Med 2000, 6(3):271-277.

4. Nunes MC, Roy NS, Keyoung HM, Goodman RR, McKhann G, Jiang L, Kang J, Nedergaard M, Goldman SA: Identification and isolation of multipotential neural progenitor cells from the subcortical white matter of the adult human brain. Nat Med 2003, 9(4):439-447.
5. Kukekov VG, Laywell ED, Suslov O, Davies K, Scheffler B, Thomas LB, O'Brien TF, Kusakabe M, Steindler DA: Multipotent stem/progenitor cells with similar properties arise from two neurogenic regions of adult human brain. Exp Neurol 1999, 156(2):333-344.

6. Pagano SF, Impagnatiello F, Girelli M, Cova L, Grioni E, Onofri M, Cavallaro M, Etteri S, Vitello F, Giombini S, Solero CL, Parati EA: Isolation and characterization of neural stem cells from the adult human olfactory bulb. Stem Cells 2000, 18(4):295-300.

7. Scolding NJ, Rayner PJ, Compston DA: Identification of A2B5-positive putative oligodendrocyte progenitor cells and A2B5-positive astrocytes in adult human white matter. Neuroscience 1999, 89(1):1-4.

8. Sanai N, Tramontin AD, Quinones-Hinojosa A, Barbaro NM, Gupta N, Kunwar S, Lawton MT, McDermott MW, Parsa AT, Manuel-Garcia Verdugo J, Berger MS, Alvarez-Buylla A: Unique astrocyte ribbon in adult human brain contains neural stem cells but lacks chain migration. Nature 2004, 427(6976):740-744

9. Akiyama Y, Honmou O, Kato T, Uede T, Hashi K, Kocsis JD: Transplantation of clonal neural precursor cells derived from adult human brain establishes functional peripheral myelin in the rat spinal cord. Exp Neurol 2001, 167(1):27-39.

10. Walton NM, Sutter BM, Chen HX, Chang LJ, Roper SN, Scheffler B, Steindler DA: Derivation and large-scale expansion of multipotent astroglial neural progenitors from adult human brain. Development 2006, 133(18):3671-3681

11. Jiang $Y$, Vaessen $B$, Lenvik $T$, Blackstad $M$, Reyes $M$, Verfaillie $C M$ : Multipotent progenitor cells can be isolated from postnatal murine bone marrow, muscle, and brain. Exp Hematol 2002, 30(8):896-904.

12. Hugnot JP, Franzen R: The spinal cord ependymal region: A neural stem cell niche in the caudal central nervous system. Front Biosci 2011, 16:1044-1059.

13. Dromard C, Guillon H, Rigau V, Ripoll C, Sabourin JC, Perrin FE, Scamps F, Bozza S, Sabatier P, Lonjon N, Duffau H, Vachiery-Lahaye F, Prieto M, Tran Van Ba C, Deleyrolle L, Boularan A, Langley K, Gaviria M, Privat A, Hugnot JP, Bauchet L: Adult human spinal cord harbors neural precursor cells that generate neurons and glial cells in vitro. J Neurosci Res 2008 86(9):1916-1926.

14. Alliot F, Rutin J, Leenen PJ, Pessac B: Pericytes and periendothelial cells of brain parenchyma vessels co-express aminopeptidase $\mathrm{N}$, aminopeptidase A, and nestin. J Neurosci Res 1999, 58(3):367-378.

15. Williams LT, Tremble $P$, Antoniades $H N$ : Platelet-derived growth factor binds specifically to receptors on vascular smooth muscle cells and the binding becomes nondissociable. Proc Natl Acad Sci USA 1982, 79(19):5867-5870.

16. Sander M, Sussel L, Conners J, Scheel D, Kalamaras J, Dela Cruz F, Schwitzgebel V, Hayes-Jordan A, German M: Homeobox gene Nkx6.1 lies downstream of Nkx2.2 in the major pathway of beta-cell formation in the pancreas. Development 2000, 127(24):5533-5540.

17. Liu R, Cai J, Hu X, Tan M, Qi Y, German M, Rubenstein J, Sander M, Qiu M: Region-specific and stage-dependent regulation of Olig gene expression and oligodendrogenesis by Nkx6.1 homeodomain transcription factor. Development 2003, 130(25):6221-6231

18. Crisan M, Yap S, Casteilla L, Chen CW, Corselli M, Park TS, Andriolo G, Sun B, Zheng B, Zhang L, Norotte C, Teng PN, Traas J, Schugar R, Deasy BM, Badylak S, Buhring HJ, Giacobino JP, Lazzari L, Huard J, Peault B: A perivascular origin for mesenchymal stem cells in multiple human organs. Cell Stem Cell 2008, 3(3):301-313.

19. Karussis D, Kassis I: The potential use of stem cells in multiple sclerosis: an overview of the preclinical experience. Clin Neurol Neurosurg 2008, 110(9):889-896.

20. Dore-Duffy P, Katychev A, Wang X, Van Buren E: CNS microvascular pericytes exhibit multipotential stem cell activity. J Cereb Blood Flow Metab 2006, 26(5):613-624.

21. Franco Lambert AP, Fraga Zandonai A, Bonatto D, Cantarelli Machado D, Pegas Henriques JA: Differentiation of human adipose-derived adult stem cells into neuronal tissue: does it work? Differentiation 2009, 77(3):221-228.

22. D'Alessandro JS, Yetz-Aldape J, Wang EA: Bone morphogenetic proteins induce differentiation in astrocyte lineage cells. Growth Factors 1994 11(1):53-69

23. Whittemore SR, Morassutti DJ, Walters WM, Liu RH, Magnuson DS: Mitogen and substrate differentially affect the lineage restriction of adult rat 
subventricular zone neural precursor cell populations. Exp Cell Res 1999, 252(1):75-95.

24. Murray K, Dubois-Dalcq M: Emergence of oligodendrocytes from human neural spheres. J Neurosci Res 1997, 50(2):146-156.

25. Compston A: From the archive "The cerebral blood-vessels in health and disease" by Pr H. Obersteiner. Brain 2007, 130:3057-3059.

26. Obersteiner $\mathrm{H}$ : The cerebral blood-vessels in health and disease. Brain 1884, 7:289-389.

27. Makariou E, Patsalides AD: Intracranial calcifications. App/ Radio/ 2009, 38(11):48-50.

28. Wegiel J, Kuchna I, Wisniewski T, de Leon MJ, Reisberg B, Pirttila T, Kivimaki T, Lehtimaki T: Vascular fibrosis and calcification in the hippocampus in aging, Alzheimer disease, and Down syndrome. Acta Neuropathol 2002, 103(4):333-343.

29. Palmer TD, Willhoite AR, Gage FH: Vascular niche for adult hippocampal neurogenesis. J Comp Neurol 2000, 425(4):479-494.

30. Kuhn HG, Dickinson-Anson H, Gage FH: Neurogenesis in the dentate gyrus of the adult rat: age-related decrease of neuronal progenitor proliferation. J Neurosci 1996, 16(6):2027-2033.

31. Goritz C, Dias DO, Tomilin N, Barbacid M, Shupliakov O, Frisen J: A pericyte origin of spinal cord scar tissue. Science 2011, 333(6039):238-242.

32. McMahon AP: Neural patterning: the role of Nkx genes in the ventral spinal cord. Genes Dev 2000, 14(18):2261-2264.

33. Cai J, Xu X, Yin H, Wu R, Modderman G, Chen Y, Jensen J, Hui CC, Qiu M: Evidence for the differential regulation of Nkx-6.1 expression in the ventral spinal cord and foregut by Shh-dependent and -independent mechanisms. Genesis 2000, 27(1):6-11.

34. Schisler JC, Fueger PT, Babu DA, Hohmeier HE, Tessem JS, Lu D, Becker TC, Naziruddin B, Levy M, Mirmira RG, Newgard CB: Stimulation of human and rat islet beta-cell proliferation with retention of function by the homeodomain transcription factor Nkx6.1. Mol Cell Biol 2008, 28(10):3465-3476.

35. Bouffi C, Thomas O, Bony C, Giteau A, Venier-Julienne MC, Jorgensen C, Montero-Menei C, Noel D: The role of pharmacologically active microcarriers releasing TGF-beta3 in cartilage formation in vivo by mesenchymal stem cells. Biomaterials 2010, 31(25):6485-6493.

36. Gordeladze JO, Noel D, Bony C, Apparailly F, Louis-Plence P, Jorgensen C: Transient down-regulation of cbfa1/Runx2 by RNA interference in murine $\mathrm{C} 3 \mathrm{H} 10 \mathrm{~T} 1 / 2$ mesenchymal stromal cells delays in vitro and in vivo osteogenesis, but does not overtly affect chondrogenesis. Exp Cell Res 2008, 314(7):1495-1506.

37. Deleyrolle L, Marchal-Victorion S, Dromard C, Fritz V, Saunier M, Sabourin JC, Tran Van Ba C, Privat A, Hugnot JP: Exogenous and fibroblast growth factor 2/epidermal growth factor-regulated endogenous cytokines regulate neural precursor cell growth and differentiation. Stem cells (Dayton, Ohio) 2006, 24(3):748-762.

38. Bieche I, Parfait B, Le Doussal V, Olivi M, Rio MC, Lidereau R, Vidaud M: Identification of CGA as a novel estrogen receptor-responsive gene in breast cancer: an outstanding candidate marker to predict the response to endocrine therapy. Cancer Res 2001, 61(4):1652-1658.

39. Marchal-Victorion S, Deleyrolle L, De Weille J, Saunier M, Dromard C, Sandillon F, Privat A, Hugnot JP: The human NTERA2 neural cell line generates neurons on growth under neural stem cell conditions and exhibits characteristics of radial glial cells. Mol Cell Neurosci 2003, 24(1):198-213,

\section{Submit your next manuscript to BioMed Central and take full advantage of:}

- Convenient online submission

- Thorough peer review

- No space constraints or color figure charges

- Immediate publication on acceptance

- Inclusion in PubMed, CAS, Scopus and Google Scholar

- Research which is freely available for redistribution

Submit your manuscript at www.biomedcentral.com/submit
Biomed Central 